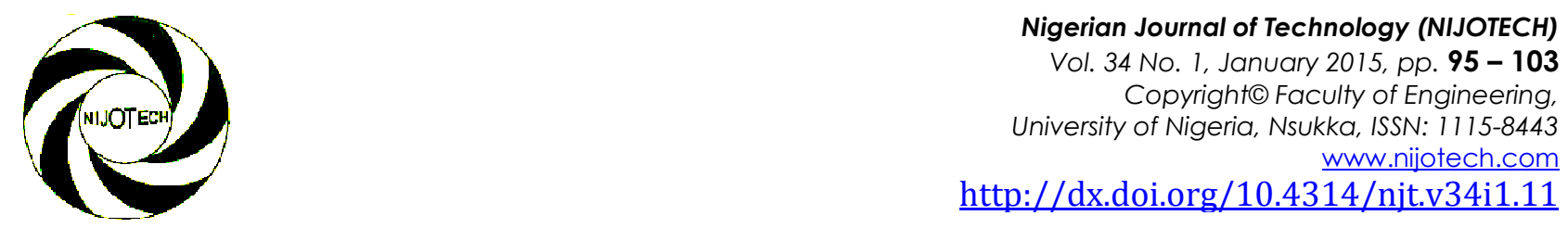

\title{
EXPERIMENTAL STUDY ON FLEXURAL RESPONSE OF FRP STRENGTHENED MASONRY BEAMS
}

\author{
C. E. Mbanusi ${ }^{1}$ and G. C. Ezeokpube ${ }^{2, *}$ \\ 1 DEPARTMENT OF BUILDING, NNAMDI AZIKIWE UNIVERSITY, AWKA, NIGERIA

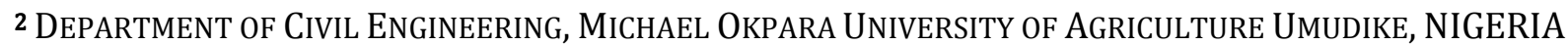 \\ E-mail Addresses:1 cyril.mbanusi@yahoo.com,2engrgreg2006@yahoo.com
}

\begin{abstract}
This paper presents experimental study on flexural response of strengthened masonry beams using Engineered Cementitious Composites (ECC), strips and carbon fibre laminates. Five sets of eleven samples were tested for flexure in four-point loading set up. Two test samples made up a set of control beams. Set two consists of three test samples strengthened using ECC strips of two centimetres thick. Four test samples strengthened using ECC strips of three centimetres thick constituted the third set. Sets four and five comprise of one test sample each; termed [i] unplastered, strengthened using carbon fibre laminates, and [ii] plastered, strengthened, using fibre laminates of carbon respectively. In terms of bending or flexural strength, deflection ductility and energy ductility parameters, samples strengthened using ECC strips and carbon fibre laminates exhibited higher values than there were for reference beams. Increased thickness of ECC strengthening strips from $2 \mathrm{~cm}$ to $3 \mathrm{~cm}$ resulted in increase in values of deflection ductility and energy ductility by $10.70 \%$ and $22.23 \%$ respectively.
\end{abstract}

Keywords: Masonry beams; Flexure; Tension- softening; Tensile-strain-hardening; ECC; Ductility; Strengthened; Carbon fibre laminates.

\section{INTRODUCTION}

Masonry structures constitute huge percentage of the building inventory in India and in most countries round the world. Many of these buildings were designed and built prior to emergence of modern building code requirements that consciously addressed care for possible effects arising from unforeseen defect causes and sources as well as some natural environment processes and systems such as earth movements of various kinds. However, reasons for strengthening or retrofitting existing buildings and infrastructure can be inevitable and are summarized by Busel and White [1] as follows:-

[i] To eliminate structural problems or distress which resulted from unusual loading or exposure conditions, inadequate design, or poor construction practices. Distress may be caused as a result of: overloads, fire, flood and foundation settlement, deterioration resulting from abrasion, fatigue effects, chemical attack, weathering, and inadequate maintenance;

[ii] To conform to current codes and standards. [iii] To allow the feasibility of changing the use of a structure to accommodate a different use from the present one;

[iv] Durability problems due to poor or inappropriate construction materials;

[v] Design or construction errors;

[vi] Aggressive environments not properly understood during the design stages;

[vii] Increased life-span demands made on ageing infrastructure;

[viii] Exceptional or accidental loading;

[ix] Varying life-span of different structural or nonstructural components.

Ehsani [2] suggested that strengthening is required for a variety of reasons including:

[i] original design errors that underestimated the actual loading on the members;

[ii] Errors of construction that resulted in a weaker member;

[iii] Increased loading on the members due to change in use; and

[iv] Improvements in analytical tools and codes that demonstrate the inadequate strength of the 
member as it was originally designed and constructed.

The traditional approach to correct the weakness of the member is by the addition of steel reinforcement [2]. This usually involves drilling and anchoring dowels into the existing member, trying a new cage of steel reinforcement to the dowels and encasing the new steel. The procedure is often very intrusive and time consuming and it adds significant weight to the existing structure. Thus, in some cases, the foundation of the structure has to be strengthened to safely carry the newly added mass [2]. Conversely, FRP consists of high resistant fibre, impregnated polymer resins, having high tensile strength, flexibility, light-weight, corrosion insensitivity, and when used for retrofitting purposes, exhibits durability, negligible additional weight, with no loss of available space, rapid application and can possess unchanging dynamic properties for structures $[3,4,5,6,7]$. FRP materials are being considered for use in strengthening/retrofitting and repairing concrete and masonry structures due to their ease of application, non-invasiveness, lightweight, high strength, high stiffness and excellent corrosion resistance even in chlorides environment [8, 9]. Numerous analytical and experimental studies have indicated that FRP-retrofits can produce significant increases in load carrying capacity and out-of-plane strength in existing masonry structures [10 - 17]. The ability to configure FRP sheets and fabrics, leads to structures that can take desired loads than the structures made of conventional materials employing conventional construction techniques [18].

Concrete technology has been undergoing brisk development during the past decade. The effort to transform the brittle performance of plain cement materials, such as cement pastes, mortars and concretes has resulted in new concepts of highperformance fibre-reinforced cementitious composites [HPFRCC], which are branded by tensile strainhardening after first cracking and multiple microcracks with tight crack width. HPFRCCs with tensile strain in excess of $3 \%$, can now be routinely produced with ordinary cement, fly ash, and aggregates. This advance is due to the development in fibre, matrix and interface properties [19 - 22]. Engineered Cementitious Composites [ECCs] are a special type of ultra HPFRCC, containing a small amount of short random fibres micromechanically designed to achieve high damage tolerance under severe loading and high durability under normal service conditions [23 -24]. ECC represents a unique group of randomly oriented short fibre-reinforced cementitious composites designed on micromechanical principles. While conventional fibre-reinforced composite polymer exhibits tension-softening after cracking, ECC strain hardens under tension with multiple cracking and features a strain-stress curve with a shape similar to that of a ductile metal with yielding point $[25,26]$. The high ductility, typically exceeds $3 \%$, associated with strain-hardening is of great significance in improving infrastructure durability against corrosion, fatigue, and resistance to structural overload. Unlike other types of high performance FRC, where the performance is boosted by using high volume fraction of fibre, the unique properties of ECC is achieved by carefully tailoring the fibre, matrix, and interface microstructures and micromechanical properties such that a minimum amount of fibre, typically less than $2 \%$ by volume, is needed. On account of low fibre content, ECC delivers best workability as well as lowest cost at the same performance base [25-27].

This article presents experimental study on flexural response of strengthened masonry beams using carbon fibre laminates and engineered cementitious composites strips. Testing of all samples was by fourpoint loading. The four-point loading set up was chosen as opposed to three-point bend test in order to avoid loading the samples directly on a particular mortar joint only and to obtain a constant moment region around the joint. This was desirable because mortar joints are the critical failure locations. This article is conceived in terms of the following objectives:- (1). To carry out experimental bend tests for control masonry beam samples, Ductile Fibre Reinforced Cementitious Composites, DFRCC or ECC, strengthened masonry beam samples and Carbon Fibre Laminates, CFL, strengthened masonry beam samples. (2). To evaluate the flexural or bending strengths of the samples. (3). To determine the flexural ductility of the samples in terms of deflection ductility, ultimate and yield energy ductility, and total and inelastic energy ductility. (4). To assess the energy ratios of the samples in order to establish their behavioural types with respect to flexural ductility responses. (5) To seek to propose, or otherwise, the use of carbon fibre laminates and ECC strips as ductile strengthening materials for deficient masonry beams.

\section{PREVIOUS WORKS ON MASONRY WALLS}

Surprisingly, previous works appear to regard masonry walls as the only masonry members of the structural masonry system. However, structural masonry system 
can also include: masonry beam, column, even slab, to mention but only a few of such examples. This literature review could not but centre on masonry walls accordingly. This constituted a degree of limitations.

Tamialan, et al. [28], investigated the flexural behaviour of unreinforced masonry (URM) walls strengthened with externally bonded FRP laminates. They also examined the effects of putty filler on the bond strength. The experimental programme consisted of twenty five masonry walls, twelve built with concrete blocks and thirteen with clay bricks. Glass FRP and Aramid FRP laminates were used to retrofit the masonry along the longitudinal axis on the tension side. They used putty filler on some specimens to fill small surface voids and provide a levelled surface to which the FRP could be adhered. Reinforcing strip widths ranged from 7.62 through $30.48 \mathrm{~cm}$. The strengthened URM wall, at being subjected to out-of-plane load, exhibited three failure modes namely: de-bonding of the FRP laminate, flexural failure by way of the FRP rupture in tension or crushing of the masonry in compression, and shear failure in the masonry near the support. Test results showed an increase in strength and stiffness of the FRP strengthened walls as compared to control specimens. It was observed that, depending upon the amount of reinforcement; increments ranging from five through twenty five times the nominal moment capacity were achieved. Debonding of the FRP laminate was determined to be the domineering failure mode. To predict the flexural capacity of simply -supported strengthened walls based on strain, internal force equilibrium, and the controlling failure mode, a model was developed. The newly developed design method provided reasonable estimates for the flexural capacities of masonry walls with externally bonded FRP laminates.

Almusallam, et al. [29], studied the behaviour of unreinforced masonry walls strengthened with fibre reinforced polymer composite materials. Six masonry walls were retrofitted with glass FRP laminates and subjected to out-of-plane and in-plane flexural and shear stresses. The two walls tested in out-of-plane bending were strengthened with one layer of bidirectional GFRP laminate on the tension side. One of the flexural walls was also retrofitted with one layer of GFRP on both sides. The out-of-plane flexural capacity was considerably enhanced by the addition of reinforcing materials. The authors viewed this as clear indication that GFRP laminates were capable of confining the wall; thereby diminishing the danger of falling debris when a wall has been subjected to damaging blast loads.

Albert, et al. [30], conducted an experimental programme to determine the effectiveness of externally applied fibre reinforced polymers in increasing the load-carrying capacity of unreinforced masonry wall subjected to out-of-plane flexural loads. The effects of the amount, type and layout of the fibre reinforcement, the effects of a compressive axial load and cyclic behaviour were all investigated. Ten masonry walls reinforced with externally applied FRP were subjected to primarily monotonically increasing lateral out-ofplane loads. One wall was loaded cyclically. Each wall was simply supported and loaded using a hydraulic jack. The results demonstrated an increase in strength and ductility of the specimens strengthened with FRP laminates as compared to control specimens.

By subjecting four full-scale unreinforced masonry walls to out-of-plane loading to failure, Tumialan, et al. [31], performed a field assessment of unreinforced masonry walls retrofitted with fibre reinforced polymer laminates. The authors identified a mechanism of failure not commonly observed in laboratory tests. Walls exhibited arching where crushing at the supports controlled the wall behaviour. It was suspected that grouting of tile units at the support regions could have induced a different and preferable failure mode. They presented an analytical model based on mechanics of the section for determining the transverse load, midheight deflection, and rotations at the supports that the walls were able to resist. Results indicated good agreement with experimental results. It is believed that the model could easily be modified to account for distributed loads acting on strengthened unreinforced masonry walls.

Triantafillou, [32], studied the strengthening of unreinforced masonry walls using epoxy-bonded FRP laminates. The effects of FRP reinforcement on masonry wall strength were examined for out-of-plane bending with axial force, in-plane bending with axial force, and in-plane shear with axial force. A total of 12 small-scale wall specimens were constructed using perforated clay brick units and tested statically in fourpoint bending set up. Six walls were tested in-plane and six were tested out-of-plane. Four of the six walls in each type of loading were reinforced with epoxybonded unidirectional CFRP laminates. The other two were used as unreinforced control specimens. Reinforcing of the walls tested in out-of-plane bending consisted of either two or four CFRP laminates bonded to their tension face. The walls were loaded to failure 
using a hydraulic testing system. All four CFRP reinforced walls tested out-of-plane failed by crushing of the masonry in the compression zone. Theoretical predictions of the failure load were made using the area fraction in the vertical direction, as well as mechanical properties determined in tension and compression tests conducted on the masonry units and FRP strips prior to the wall tests. The increase in outof-plane bending capacity depends on the products of the area fraction and the elastic modulus of the FRP. Hence, laminates with higher stiffness were found to be more efficient in masonry reinforcement. The experimental failure loads of the strengthened samples were approximately ten times the failure loads of the control specimens. This staggering difference boldly demonstrates the effectiveness of the CFRP laminates strengthening technique for masonry walls.

\section{MATERIALS AND METHODS}

\subsection{Strategy and Effect of Strengthening}

Strategy of strengthening should first and foremost focus on comprehensive study to actually identify and fully understand the nature and extent of the structural deficiency existing in the structure or structural member. It should equally involve the actual redesign of the structural requirements so as to target and achieve an acceptable level of safety. Of prime importance is also to ensure that any conceptual and construction errors were appropriately ratified and rectified. Effect of strengthening can come about by way of enhancement or increase of one or more than one of the following parameters such as: (i) tensile capacity; (ii) shear capacity; (iii) flexural capacity; (iv) compressive capacity; (v) member stability; (vi) ductility; and (vii) strength or stiffness or both.

\subsection{Test Samples Programme}

A total of eleven samples in five sets were tested using the four-point loading set up shown in Plate 1 . Set 1 is tagged PU - plastered un-strengthened masonry beams. This comprises of two samples representing the control specimens. Set 2 or SP2 to imply: Plastered strengthened using ECC strip of $2 \mathrm{~cm}$ thick. There were three test samples in this group namely: SP21, SP22 and SP23 respectively. SP3 or set 3 represents: Plastered, Strengthened samples using ECC strip of 3 $\mathrm{cm}$ thick. Here, four specimens were tested namely SP31, SP32, SP33 and SP34 respectively. The loaddeflection results obtained for set 1 and set 2 are plotted in Figures 2 and 3 respectively. The fourth set of tested sample is termed UPSC or Un-plastered strengthened, using carbon fibre laminates. One sample was involved in this set. Finally, set 5 included: Plastered sample and strengthened using carbon fibre laminate [PSC]. Here, one sample was also tested. Each of the test samples is of dimensions: $150 \mathrm{~cm}$ long, 14 $\mathrm{cm}$ deep and $11 \mathrm{~cm}$ wide. On separate notes, results of tests for each set were combined so as to present common figures for the sets affected. These were portrayed by way of: PU Combined; SP2 Combined and SP3 Combined, respectively. Figure 3, tagged 'trendline', shows results of SP2, SP3 and PU put together.

\section{EXPERIMENTAL PROGRAMME}

Manufacture of Ductile Fibre Reinforced Cementitious Composites [DFRCC], known as Engineered Cementitious Composites [ECC] strips are of dimensions: $130 \mathrm{~cm}$ long $\mathrm{x} 10 \mathrm{~cm}$ wide and of thicknesses $2 \mathrm{~cm}$ and $3 \mathrm{~cm}$. They were cast using the following composition as shown in Plate 1 Table 1: Composition for $1 \mathrm{~m}^{3}$ of DFRCC.

\begin{tabular}{ll}
\hline Material & Quantity $(\mathrm{Kg})$ \\
\hline Cement & 452 \\
Fly Ash & 452 \\
Silica Sand & 452 \\
Water & 199 \\
Plasticizer & 9.03 \\
Recron Fiber & 20 \\
\hline
\end{tabular}

Table 2: Masonry beams of dimensions: $150 \mathrm{~cm}$ long $X$ $11 \mathrm{~cm}$ wide $x 140 \mathrm{~cm}$ deep, cast but cured for 28 days.

\begin{tabular}{ll} 
Usage & No. of Sample \\
\hline Control Beam & 3 \\
$\begin{array}{l}\text { Strengthened with DFRCC } \\
\text { Strips of 2cm thickness }\end{array}$ & 3 \\
$\begin{array}{l}\text { Strengthened with DFRCC } \\
\text { strips of 3cm thickness }\end{array}$ & 4 \\
\hline
\end{tabular}
strips of $3 \mathrm{~cm}$ thickness $\quad 4$

All the beams, control and strengthened, are tested in four-point loading with distance between two downward loading application points being $10 \mathrm{~cm}$ and span of simply supported beam being $90 \mathrm{~cm}$.

Table 3: Maximum load and deflection for masonry beams strengthened with DFRCC strips of 2cm thickness.

\begin{tabular}{ccc}
\hline Sample & Maximum load $(\mathrm{kg})$ & Maximun deflection $(\mathrm{mm})$ \\
\hline SP21 & 800 & 1.7 \\
SP22 & 750 & 1.8 \\
SP23 & 1000 & 1.8 \\
\hline
\end{tabular}

Table 4: Maximum load and deflection for masonry beam samples strengthened with DFRCC strips thickness of $3 \mathrm{~cm}$.

\begin{tabular}{ccc}
\hline Sample & $\begin{array}{c}\text { Maximum load } \\
(\mathrm{kg})\end{array}$ & $\begin{array}{c}\text { Maximum deflection } \\
(\mathrm{mm})\end{array}$ \\
\hline SP31 & 1200 & 2.4 \\
SP32 & 1000 & 2 \\
SP33 & 1000 & 2 \\
\hline
\end{tabular}




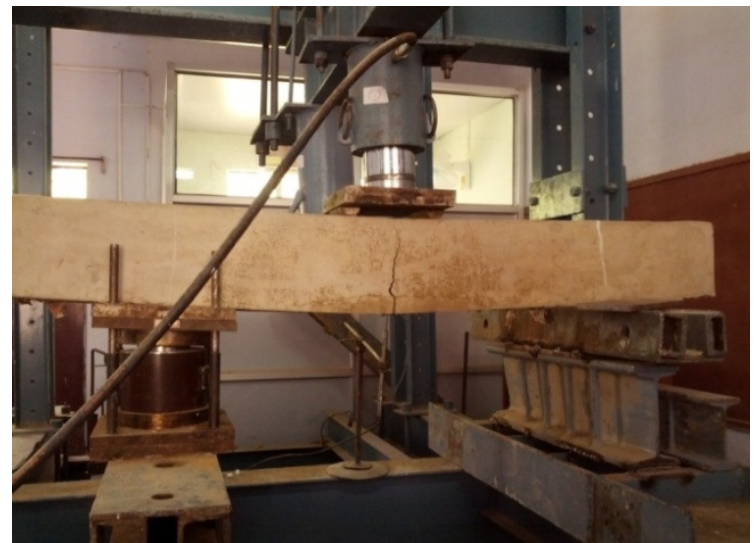

Plate 1: Typical four-point loading set up for the tested samples (control and strengthened)

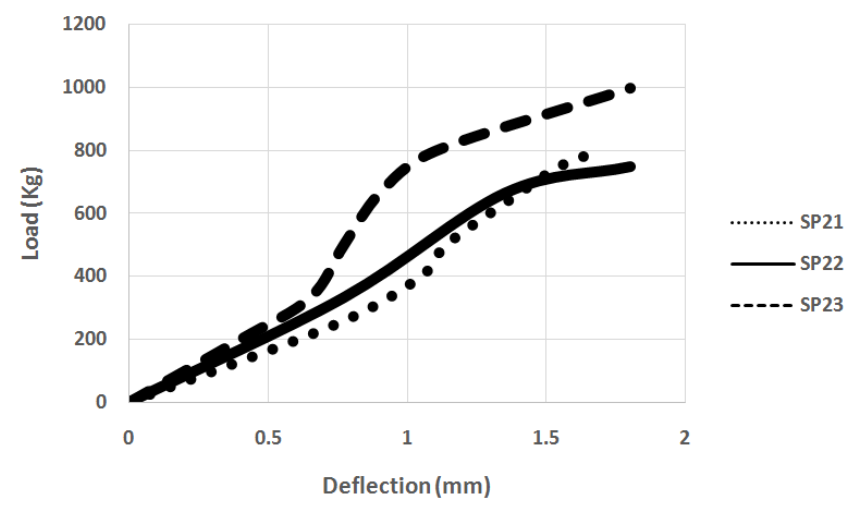

Figure 1: Test results summary for masonry beams strengthened with ECC strip of $2 \mathrm{~cm}$ thickness.

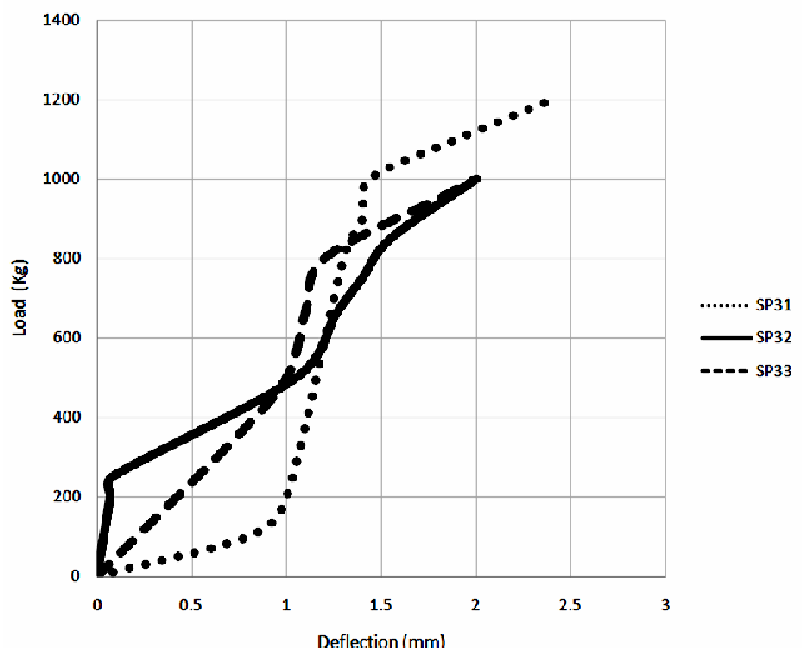

Figure 2: Test results summary for masonry beam samples strengthened with DFRCC strips of $3 \mathrm{~cm}$.

Table 5: Test results summary for the first three sets of tests with respect to maximum load and deflection.

\begin{tabular}{llll}
\hline Sample & PU & SP2 & SP3 \\
\hline Maximum Load (Kg) & 210 & 850 & 1133.4 \\
Maximum Deflection (mm) & 0.825 & 1.76 & 2.13 \\
\hline
\end{tabular}

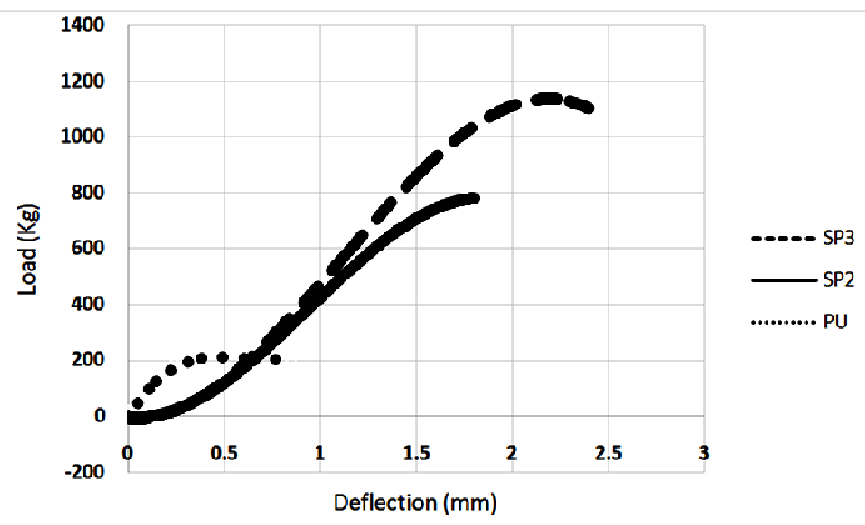

Figure 3: Comparison of test results for the first three sets of the tests (Trend-line).

\section{ANALYSIS OF RESULTS}

\subsection{Bending Strength or Modulus of Rupture}

For the static four-point loading applied for all tests for the experiment, distance between two central load application points, $\mathrm{L}_{1},=100 \mathrm{~mm}$, and effective span of each sample, $L_{,}=900 \mathrm{~mm}$. Since the loading span, $\mathrm{L}_{1}$, is neither equal to one third nor equal to a half of the span for the static four-point loading, then the bending strength or modulus of rupture, $\delta_{b}$, would be obtained by: $\delta_{b}=3 \mathrm{P}(\mathrm{L}-\mathrm{L} 1) / 2 \mathrm{bd}^{2}$. Where: $\mathrm{b}=110 \mathrm{~mm}$, and $\mathrm{d}$ $=140 \mathrm{~mm}$, are the breadth and depth of each of the test sample beams respectively. $\mathrm{P}=$ the load magnitude when the test sample breaks. The bending strength for the tested samples is given in Table 6 .

Table 6: Bending strength for the tested samples.

\begin{tabular}{|c|c|c|c|}
\hline $\begin{array}{l}\text { Tested } \\
\text { sample }\end{array}$ & $\begin{array}{l}\text { Binding } \\
\text { Strength } \\
\left(\mathrm{N} / \mathrm{mm}^{2}\right)\end{array}$ & $\begin{array}{l}\text { Tested } \\
\text { Sample }\end{array}$ & $\begin{array}{l}\text { Binding } \\
\text { Strength } \\
\left(\mathrm{N} / \mathrm{mm}^{2}\right)\end{array}$ \\
\hline $\begin{array}{l}\text { PU1 } \\
\end{array}$ & 0.872 & SP31 & 4.880 \\
\hline PU2 & 0.900 & SP32 & 3.771 \\
\hline $\begin{array}{l}\text { PU } \\
\text { combined }\end{array}$ & 0.922 & SP33 & 4.215 \\
\hline SP21 & 3.327 & SP34 & 4.436 \\
\hline SP22 & 2.955 & $\begin{array}{l}\text { SP3 } \\
\text { combined }\end{array}$ & 4.880 \\
\hline SP23 & 3.549 & UPSC & 7.985 \\
\hline $\begin{array}{l}\text { SP23SP2 } \\
\text { combined }\end{array}$ & 3.327 & PSC & 7.985 \\
\hline
\end{tabular}

\subsection{Deflection Ductility and Energy Ductility.}

Ductility is assessed in terms of dimensionless deflection or energy ratios. Using these parameters, ductility, $\mu$, relative to the yield condition, is defined as:

$$
\mu_{d}=\frac{\Delta_{u}}{\Delta_{y}} ; \mu_{E}=\frac{E_{u}}{E_{y}} \text { and } E=\int P d \Delta
$$

In (1), $\mu_{d}$ is deflection ductility, $\mu_{E}$ is energy ductility, $\Delta_{u}$ is the ultimate center span deflections, $\Delta_{y}$ is the 
yield center span deflections, $\mathrm{E}_{\mathrm{u}}$ is the area under the load deflection diagram at ultimate and $\mathrm{E}_{\mathrm{y}}$ is the area under the load deflection diagram at yield.

Jeong [33], expressed the ductility of members, disregarding the existence of yielding phenomenon, with a new ductility index - the Naaman index, using the energy ratio,

$$
\mu=\frac{1}{2}\left(\frac{E_{\text {total }}}{E_{\text {elastic }}}+1\right)
$$

In (2), $\mathrm{E}_{\text {total }}$ is the total energy absorbed by the sample,

$E_{\text {elastic }}$ is the eleastic energy absorbed by the sample. Numerical integration of the load-deflection graph was used to determine $E_{u}, E_{y}, E_{\text {elastic }}$, and $E_{\text {total }}$

Results of ductility are summarized in Table 7.

Table 7: Summary of ductility results - Deflection ductility.

\begin{tabular}{lllllll}
\hline Sample & $\mathrm{P}_{\mathrm{u}}(\mathrm{Kg})$ & $\mathrm{P}_{\mathrm{y}}(\mathrm{Kg})$ & $\Delta_{\mathrm{u}}(\mathrm{mm})$ & $\Delta_{\mathrm{y}}(\mathrm{mm})$ & $\Delta_{\mathrm{u}} / \Delta_{\mathrm{y}}$ & Ratio \\
\hline PU1 & 213.084 & 208 & 0.85 & 0.61 & 1.39 & 1.00 \\
PU2 & 207.874 & 201 & 0.80 & 0.59 & 1.35 & 1.00 \\
PUcombined & 213.084 & 210 & 0.85 & 0.61 & 1.39 & 1.00 \\
SP21 & 800 & 500 & 1.7 & 1.15 & 1.47 & 1.05 \\
SP22 & 750 & 600 & 1.8 & 1.25 & 1.44 & 1.03 \\
SP23 & 1000 & 800 & 1.8 & 1.10 & 1.63 & 1.17 \\
SP2combineed & 800 & 600 & 1.8 & 1.20 & 1.50 & 1.07 \\
SP31 & 1200 & 1000 & 2.4 & 1.5 & 1.6 & 1.15 \\
SP32 & 1000 & 500 & 2 & 1.1 & 1.81 & 1.3 \\
SP33 & 1000 & 800 & 2 & 1.2 & 1.66 & 1.19 \\
SP34 & 1200 & 1000 & 1.8 & 1.0 & 1.8 & 1.29 \\
SP3 combined & 1200 & 1000 & 2.4 & 1.5 & 1.6 & 1.15 \\
UPSC & 2000 & 1100 & 3.6 & 2.2 & 1.63 & 1.17 \\
PSC & 2000 & 1225 & 2.2 & 1.35 & 1.62 & 1.16 \\
\hline
\end{tabular}

Table 8:- Summary of ductility results - Ultimate and yield energy ductility.

\begin{tabular}{lllllll}
\hline Sample & $\mathrm{P}_{\mathrm{u}}(\mathrm{kg})$ & $\mathrm{P}_{\mathrm{y}}(\mathrm{kg})$ & $\mathrm{E}_{\mathrm{u}}(\mathrm{Nmm})$ & $\mathrm{E}_{\mathrm{y}}(\mathrm{Nmm})$ & $\Delta_{\mathrm{u}} / \Delta_{\mathrm{y}}$ & $\mathrm{Ratio}$ \\
\hline PU1 & 213.084 & 208 & 1410 & 894 & 1.57 & 1.00 \\
PU2 & 207.874 & 201 & 1329 & 822 & 1.61 & 1.00 \\
PU combined & 213.084 & 210 & 1422 & 887 & 1.60 & 1.00 \\
SP21 & 800 & 500 & 5218 & 2280 & 2.28 & 1.41 \\
SP22 & 750 & 600 & 7553 & 3408 & 2.21 & 1.37 \\
SP23 & 1000 & 800 & 9859 & 4095 & 2.40 & 1.49 \\
SP2 combined & 800 & 600 & 5670 & 2427 & 2.33 & 1.44 \\
SP31 & 1200 & 1000 & 13245 & 3850 & 3.43 & 2.13 \\
SP32 & 1000 & 408 & 11085 & 3328 & 3.33 & 2.06 \\
SP33 & 1000 & 800 & 10251 & 3060 & 3.35 & 2.08 \\
SP34 & 1200 & 1125 & 16775 & 4848 & 3.46 & 2.14 \\
SP3 combined & 1200 & 550 & 14224 & 4040 & 352 & 2.18 \\
USPC & 2000 & 1260 & 35316 & 11247 & 3.14 & 1.95 \\
SPC & 2000 & 1225 & 16677 & 5297 & 3.14 & 1.95 \\
\hline
\end{tabular}

Table 9:- Ductility Results - Total and elastic Energy Ductility using Naaman Index.

\begin{tabular}{|c|c|c|c|c|c|c|}
\hline Sample & $\begin{array}{c}\mathrm{Pu}_{\mathrm{u}} \\
(\mathrm{kg})\end{array}$ & $\begin{array}{l}\text { Pelastic } \\
(\mathrm{kg})\end{array}$ & Etotal $(\mathrm{Nm})$ & $\begin{array}{c}\text { Eelastic } \\
(\mathrm{Nmm})\end{array}$ & $\begin{array}{c}\mu= \\
1 / 2\left(\text { Etotal }_{\text {tolastic }}+\right)\end{array}$ & Ratio \\
\hline PU1 & 213.084 & 109 & 1410 & 641 & 1.59 & 1.00 \\
\hline PU2 & 207.874 & 119 & 1329 & 604 & 1.60 & 1.00 \\
\hline PU combined & 213.084 & 118 & 1422 & 646 & 1.60 & 1.00 \\
\hline SP21 & 800 & 154 & 5218 & 1304 & 2.50 & 1.56 \\
\hline SP22 & 750 & 198 & 7553 & 1888 & 2.50 & 1.56 \\
\hline SP23 & 1000 & 207 & 9859 & 2347 & 2.60 & 1.62 \\
\hline SP2 combined & 800 & 288 & 5670 & 1383 & 2.54 & 1.58 \\
\hline SP31 & 1200 & 562 & 13243 & 2283 & 3.40 & 2.12 \\
\hline SP32 & 1000 & 331 & 11085 & 1944 & 3.35 & 2.09 \\
\hline SP33 & 1000 & 327 & 10251 & 1767 & 3.40 & 2.12 \\
\hline SP34 & 1200 & 593 & 16775 & 2872 & 3.42 & 2.13 \\
\hline SP3 combined & 1200 & 360 & 14224 & 2452 & 3.40 & 2.12 \\
\hline UPSC & 2000 & 781 & 35316 & 6588 & 3.18 & 1.98 \\
\hline PSC & 2000 & 780 & 16677 & 3111 & 3.18 & 1.98 \\
\hline
\end{tabular}


Table 10: Energy Ratio

\begin{tabular}{|c|c|c|c|c|c|}
\hline Sample & $\begin{array}{c}\text { Etotal } \\
(\mathrm{Nmm})\end{array}$ & $\begin{array}{c}\text { Einelastic } \\
(\mathrm{Nmm})\end{array}$ & $\mathrm{E}_{\text {inelastic }} / \mathrm{E}_{\text {total }}$ & $\begin{array}{c}\text { Energy } \\
\text { ratio (\%) }\end{array}$ & $\begin{array}{c}\text { Type of } \\
\text { behaviour }\end{array}$ \\
\hline PU1 & 1410 & 769 & 0.55 & 55 & Non ductile \\
\hline PU2 & 1329 & 725 & 0.55 & 55 & Non ductile \\
\hline PU combined & 1422 & 776 & 0.55 & 55 & Non ductile \\
\hline SP21 & 5218 & 3914 & 0.75 & 75 & Just ductile \\
\hline SP22 & 7553 & 5665 & 0.75 & 75 & Just ductile \\
\hline SP23 & 9859 & 7512 & 0.76 & 76 & Just ductile \\
\hline SP2 combined & 5670 & 4287 & 0.76 & 76 & Just ductile \\
\hline SP31 & 13243 & 10960 & 0.83 & 83 & Ductile \\
\hline SP32 & 11085 & 9141 & 0.82 & 82 & Ductile \\
\hline SP33 & 10251 & 8484 & 0.83 & 83 & Ductile \\
\hline SP34 & 16775 & 13903 & 0.83 & 83 & Ductile \\
\hline SP3 combined & 14224 & 11772 & 0.83 & 83 & Ductile \\
\hline UPSC & 35316 & 28728 & 0.81 & 81 & Ductile \\
\hline PSC & 16677 & 13566 & 0.81 & 81 & Ductile \\
\hline
\end{tabular}

\subsection{Summary of Results}

Carbon fibre laminates strengthening exhibits the greatest bending strength level, recording the highest values for the modulus of rupture as shown in Table 6 . This is followed by strengthening with ECC which showed increasing bending strength with increase in thickness of strengthening strip from $2 \mathrm{~cm}$ to $3 \mathrm{~cm}$. Strengthened masonry beams demonstrate significantly higher bending strength, as compared to the control samples.

Strengthening with Engineered Cementitious Composites, ECC, of $2 \mathrm{~cm}$ thick, raises the ductility index of those members appreciably. This also brings the type of behaviour of these members to just ductile, since ductile behaviour begins from $75 \%$ energy ratio or ductility index of 2.5 for flexural members, Grace et $\mathrm{al}$, (34). ECC strengthening strip of $3 \mathrm{~cm}$ thick, further raises both the ductility index and energy ratio of these flexural members to the level which enhances their ductile type of behaviour, Table 10 .

\section{CONCLUSIONS}

The following classes of masonry beams were used in the experimental study: (1) Control or reference sample beam; (2) Masonry beam, set 2, strengthened with ECC of $2 \mathrm{~cm}$ thickness; (3) Masonry beam, set 3, strengthened with ECC of $3 \mathrm{~cm}$ thickness; (4) Masonry beam, set 4, strengthened with unplastered carbon laminate and (5) Masonry beam, set 5, strengthened with plastered carbon laminate. Based on the study the following inferences could be made:

With reference to Table 6, the flexural strength for set 2 and set 3 masonry beams were, averagely, higher than that of the control beams by about $72.96 \%$ and $79.52 \%$ respectively. The flexural strengths for both set 4 and set 5 were $88.90 \%$ higher than that of the control beams. In addition the flexural strength of set 3 was higher than that of set 2 by about $8.25 \%$.

In terms of deflection ductility, Table 7a refers. The deflection ductility of set 2 and set 3 masonry beams were, averagely, higher than that of the control beams by about $9.30 \%$ and $20.00 \%$ respectively. The deflection ductility of both set 4 and set 5 were $15.95 \%$ higher than that of the control beams.

In terms of ultimate and yield energy ductility, Table $7 \mathrm{~b}$ refers. In this case the energy ductility for set 2 and set 3 masonry beams were, averagely, higher than that of the control beams by about $30.87 \%$ and $53.10 \%$ respectively while the energy ductility for both set 4 and set 5 were $49.36 \%$ higher than that of the control beams.

In terms of total and elastic energy ductility, Table 7c refers. In this case the energy ductility for set 2 and set 3 masonry beams were, averagely, higher than that of the control beams by about $36.96 \%$ and $52.98 \%$ respectively while the energy ductility for both set 4 and set 5 were $52.98 \%$ higher than that of the control beams.

It can, therefore, be concluded that

1) Increase in ECC strengthening strip thickness resulted in increase in ductility for the ECC strengthened beams. This is evident from Table 8.

2) In the case of strengthening of masonry beams for flexural ductility, it is advisable to use ECC thickness of not less than $3 \mathrm{~cm}$.

3) Carbon fibre laminates and Engineered Cementitious Composites (ECC) can offer credible retrofitting materials for deficient flexural masonry beams. 


\section{REFERENCES}

[1]. Busel, J. and White, D., “CFRP \& GFRP Composite Applications for Infrastructure Rehabilitation and Repairs," Presented on behalf of Sika Corporation on NASTO 2003 Conference Saratoga Springs, NY. USA., 2003.

[2]. Ehsani, M., Strengthening of Concrete and Masonry Structures with Fibre Reinforced Polymer (FRP)" $30^{\text {th }}$ Conference on our World Concrete and Structures," Singapore, 23 - 24 August, 2005.

[3]. Ehsani, R., Saadatmanesh, H., and Alsaidy, A., "Shear Behaviour of URM Wall Retrofitted with FRP Overlays." J. Comp. for Constr., ASCE, 1(1), 1997, pp. $17-25$.

[4]. Kolsch, H. " Carbon Fibre Cement Matrix (CFCM) Overlay System for Masonry Strengthening." J. of Comp. for Constr., ASCE, 2(2), 1998, pp 105 - 109.

[5]. Velazquez-Dimas, J.I., Saadatmanesh, H., and Ehsani, M. R., "Behaviour of Retrofitted URM Walls Under Simulated Earthquake Loading." J. Comp. for Constr., 3(3), 1999, pp. $134-142$.

[6]. Tinazzi, D., Modena, C., and Nanni, A., "Strengthening of Masonry Assemblage with FRP Rods and Laminates." International Meeting on Composite Materials, PLAST 2000, pp. 411 - 418.

[7]. Tumalan, G., Michelli, F., and Nanni, A., "Strengthening of Masonry Structures with FRP Composites." Structures, 2001 Washington D.C. May $21-23,2001$, pp. $2-4$.

[8]. Tong, L., Galati, N., Tumialan, G., and Nanni., A., "Analysis of Unreinforced Masonry Concrete Walls Strengthened with Glass Fibre Reinforced Polymer Bars," ACI Structural Journal Vol. 102, No. 4July August, 2005, pp. 569 - 577.

[9]. Creazza, G., Saetta, A.V., Matteazzi, R., and Vitaliani, R.V., "Analysis of Masonry Structures Reinforced by FRP," Historical Constructions, P.B. Lourenco, P. Roca(Eds), Guimaraes, 2001, pp. 539 - 545.

[10]. Ascione, L., and Feo, L., "Modelling of Composites/ Concrete Interface of RC beams Strengthened with Composite Laminates." Compos Part B: Eng 2000:31: pp. 535 - 540 .

[11]. Ascione, L., Berardi, V.P., Feo, L., and Mancusi, G.," A Numerical Evaluation of the Interlaminar Stress State in Externally FRP Plated R.C. Beams ." compos Part B: Eng 2005:36: pp. 83 - 90.

[12]. Heyman, J., The Stone Skeleton. Cambridge, UK Cambridge University Press, London, 1995.

[13]. Del, P.G. "Limit Analysis and no Tension Materials." Int J Plasticity, 1998:14: pp. 259 - 271.

[14]. Lucchesi, M., Padovani, C., Pasquinelli, G., and Zani, N.,"On the Collapse of Masonry Arches." Meccanica 1997: 32 : pp. 327 - 346.
[15]. Giacquinta, M., and Giusti, G., "Researches on the Equilibrium of Masonry Structures." Arch Rat Mech Analysis 1985: 88: pp. 359 - 392.

[16]. Del, P.G., "Constitutive Equations and Compatibility of the External Loads for Linear Elastic Masonrylike Materials." Meccanica 1989:24: pp. 150 - 162.

[17]. Lofti, H., and Shing, P., "Interface Model Applied Fracture of Masonry Structures." ASCE Structural Journal1994, Vol. 102 pp. 63 - 80.

[18]. Vijay, P.V., and Ganga, R., "Development of Fibre Reinforced Plastics for Highway Application: Aging Behaviour of Concrete Beams Reinforced with GFRP Bars." CFC-WVU Report No. 99 - 265, WVDOH RP\#T-669-FRPI 1999.

[19]. Lepech, M. D., and Li, V. C., Water Permeability in Engineered Cementitious Composites. Journal of Cement and Concrete Composites, Vol. 31, No. 10, 2009 , pp. $744-753$.

[20]. Miyazato, S., and Hiraishi, Y., "Transport Properties and Steel Corrosion in Ductile Fibre Reinforced Cement Composites." Proc., 11th International Conference on Fracture (CD-ROM), Turin, Italy, March 20-25, 2005, http://www.ic11.com/ proceeding/EXTENDED/4484.pdf.AccessedMay $\underline{2010}$.

[21]. Sahmaran, M., Li, M., and Li, V. C. "Transport Properties of Engineered Cementitious Composites Under Chloride Exposure." ACI Materials Journal, Vol. 104, No. 6, 2007, pp.604-611.

[22]. Martys, N. S., and Ferraris, C. F., "Capillary Transport in Mortars and Concrete." Cement and Concrete Research, Vol. 27, No. 5. 1997, pp. 747760.

[23]. Sahmaran, M., and Li, V. C., "Influence of Microcracking on Water Absorption and Sorptivity of ECC. RILEM Materials and Structures, Vol.42, No. 5, 2009, pp. 593-603.

[24]. Kanda, T., Saito, T., and Sakata, N., "Tensile and AntiSpalling Properties of Direct Sprayed ECC." Advanced Concrete Technology, Vol. 1., No. 3, 2003. pp. 269-282.

[25]. Sahmaran, M., Li, V. C., and Andrade, C., "Corrosion Resistance Performance of Steel-Reinforced Engineered Cementitious Composites Beams. ACI Material Journal, Vol. 105, No. 3, 2008, pp. 243.

[26]. Li, V. C., Fischer, G., Kim, Y. Y., Lepech, M., Qian, S., Weimann, M., and Wang, S., "Durable Link Slabs for Jointless Bridge Decks Based on Strain-Hardening Cementitious Composites. Report for Michigan Department of Transportation. RC-1438, Ann Arbor, Mich., Nov., 2003.

[27]. Sahmaran, M., Lachemi, M., and Li, V. C., "Assessing the Durability of Engineered Cementitious Composies Under Freezing and Thawing Cycles, Journal of ASTM International, Vol. 6, No. 7, 2009. 
[28]. Tumialan, G. J., Nanni, A., and Galati, N.,"FibreReinforced Polymer Strengthening of Unreinforced Masonry Walls Subjected to Out-of-Plane Loads." ACI Structural Journal, Vol. 100, No. 3, May-June, 2003, pp. 321-329.

[29]. Almusallam, T. H., Al-Salloum, Y. A., Alsayed, S. H., and Mosallam, A. S., "Behaviour of Unreinforced Masonry Walls (URM) Strengthened with FRP Composite Materials." Proceedings of International SAMPE Symposium and Exhibition, Vol. 46, No. 1, 2001, pp. 473-484.

[30]. Albert, M. L., Elwi, A. E., and Cheng, J. J. R., "Strengthening of Unreinforced Masonry Walls using FRPs." Journal of Composites for Construction, Vol. 5, No. 2, 2001, pp. 76-84.

[31]. Tumialan, G.J., Galati, N., and Nanni, A.,"Field Assessment of Unreinforced Masonry Strengthened with Fibre Reinforced Polymer Laminates." Journal of Structural Engineering, Vol. 129, No. 8, 2003, pp.1047-1056.

[32]. Triantafillou, T. C., "Strengthening of Masonry Structures using Epoxy-bonded FRP laminates." Journal of Composites for Construction, Vol. 2, No. 2, 1998, pp. 96-104.

[33]. Jeong, S. M., "Evaluation of Ductility in Pre-stressed Concrete Beams using Fibre-Reinforced Plastic Tendons." Ph.D. thesis, Univ. of Michigan, Ann Arbor, Mich, 2007.

[34]. Grace, N. F., Soliman, A. K., Abdel-Sayed, G., and Saleh, K. R., "Behaviour and Ductility of Simple and Continuous FRP Reinforced Beams." Journal of Composites and Construction, Vol.2, No.4, 2005, pp. 186-194. 